\title{
Production economics of sustainable soil management based cauliflower (Brassica oleracea L. var. botrytis) in Dhading district of Nepal
}

\author{
Binod Ghimire ${ }^{1, *}$, Shiva Chandra Dhakal ${ }^{2}$ \\ ${ }^{1}$ Agriculture Extension Officer, District Agriculture Development Office, Mustang, Ministry of Agricultural Development, Government \\ of Nepal, Nepal \\ ${ }^{2}$ Department of Agricultural Economics, Institute of Agriculture and Animal Science, Tribhuvan University, Rampur, Chitwan, Nepal
}

\section{Email address:}

binodghim@gmail.com (B. Ghimire)

\section{To cite this article:}

Binod Ghimire, Shiva Chandra Dhakal. Production Economics of Sustainable Soil Management Based Cauliflower (Brassica Oleracea L. Var. Botrytis) in Dhading District of Nepal. American Journal of Agriculture and Forestry. Vol. 2, No. 4, 2014, pp. 199-205.

doi: 10.11648/j.ajaf.20140204.23

\begin{abstract}
Study investigated the production economics of sustainable soil management based cauliflower conducted at Nalang VDC of Dhading District in Nepal. It was based on primary data for the year 2012 obtained from randomly selected 60 sustainable soil management based cauliflower producers using pre-tested semi-structured interview schedule. Findings of the study revealed that, per ropani total cost of sustainable soil management based cauliflower production was lower whereas, gross income and gross margin were significantly higher by NRs. 1749.58 and 2173.36 respectively compared to before sustainable soil management practices in the study area. Also, comparatively higher benefit-cost ratio (4.26) and higher return to scale $(0.802)$ was observed from sustainable soil management based cauliflower production. Similarly, production function analysis revealed that one percent increase in the use of hired human labor, expenditure on seed and expenditure on chemical inputs would increase the yield of cauliflower by $0.027,0.362$ and 0.177 percent respectively. Resource use efficiency analysis resulted that the resources were not utilized to their optimum economic level. For optimum allocation of resources expenditure on seed, chemical inputs and organic manure is required to increase by 96.1 percent, 87.5 percent and 72.0 percent respectively whereas, expenditure on human labor is required to decrease by 116.0 percent.
\end{abstract}

Keywords: Benefit-Cost Ratio, Cauliflower, Production Economics, Production Function, Resource Use Efficiency, Sustainable Soil Management, Nepal

\section{Introduction}

Cauliflower (Brassica oleracea L. var. botrytis) is an annual highly nutritive vegetable belong to family Brassicacae and reproduce by seeds. It originated from northeast Mediterranean and presently cultivated all over the world. It is an important commercial vegetable grown in Nepal and is also one of the highly preferred vegetables in Nepalese kitchen. Also, in Dhading district cauliflower is prioritized in production and marketing. The total production of vegetables in Dhading district in year 2011/12 was 74797 metric tons under total area of 6051 hectare with the yield of $12361 \mathrm{~kg} / \mathrm{ha}$. and cauliflower contributes $7054 \mathrm{mt}$. from 495 hectares (MoAD, 2012) of land. Contribution of the district in total vegetable supply to Kalimati vegetable market, Kathmandu was 17.68 percent in 2012/13 with total supply of 41,555 Mt. including 7,560 tons of tomato, 8,533 tons of cauliflower, 2,588 tons of beans and 2,752 tons of bitter gourd (KFVMDB, 2012).

The total area, production and productivity of vegetable in Nepal are 245037 hectare, $3298816 \mathrm{mt}$. and 13.46 ton/ha. respectively and the contribution of vegetables in AGDP is 20.74\% (MoAD, 2012). Tomato, cauliflower, cabbage, cucumber, onion and chili are the major off-season vegetables of Nepal which generates income for household 
and among them, the cultivation of tomato, cauliflower, and cabbage are the most popular and the most profitable (NARC, 2006). Awasthi (2003) also reported cultivation of more than 247 vegetable crops in Nepal and out of which 50 species and their varieties are grown at commercial scale.

Sustainable Soil Management Program (SSMP) targets improvements in soil fertility and productivity in rain fed upland-dominated farming systems in the mid hills of Nepal with the aim of increasing food production, food security and farm incomes (SSMP, 2009). SSM practices includes improved farm yard manure, improved cattle sheds and urine use, legume integration, use of biopesticides, botanical pesticides, integrated plant nutrient systems, fodder promotion for livestock, SSM-based vegetable production etc. Moreover, the introduction of SSM practices has a direct role in improving the nutrition of many mid-hill households, in terms of both quantity and quality. These practices tends to reduce the use of fertilizer, pesticides and maximal tillage but rely more on crop rotation, crop residues, animal manure, green manure, leguminous crops, appropriate mechanical control or minimal tillage to optimize soil conservation activity (Noorivandi et al., 2009). But the farmers have not adequately applied these measures to enhance overall system productivity because they are deprived of the access to resources, knowledge and skills on sustainable soil fertility management (FORWARD, 2006). Thus in-depth economic analysis of SSM based production system is urgent.

In Nepal, very little research has been carried out on the use, effect and economics of such sustainable soil management based crop production. This study will assess the economic significance of SSM-based cauliflower production compared with before.

The general objective of this research was to assess the comparative economics of sustainable soil management based cauliflower production. However, the specific objectives were;

i. To illustrate socio-demographic characteristics of selected SSM based cauliflower producers.

ii. To analyze benefit cost of SSM based cauliflower production compared with conventional system along with determinants factors of production.

iii. To analyze resource use efficiency in SSM based cauliflower production.

\section{Materials and Methods}

\subsection{Study Area}

The research was conducted at Nalang Village Development Committee (VDC) of Dhading district in Nepal where sustainable soil management program was conducted successfully for about five years and is also one of the major vegetable producing districts of the country. Dhading district spreads from 27'40"E to 28'17"E and $80^{\prime} 17^{\prime \prime} \mathrm{N}$ to $84^{\prime} 35^{\prime \prime} \mathrm{N}$.

\subsection{Sampling Method and Data Collection Procedure}

The cauliflower producers adopting SSM practices were taken as the sample population for this study. A sample size of 60 is generally regarded as the minimum requirement for larger population that yields a sufficient level of certainty for decision-making (Poate and Daplyn, 1993). Such that, 60 SSM based cauliflower producers from Nalang VDC of Dhading district were selected for the study. Primary data was collected with the aid of a semi-structured interview schedule using simple random sampling technique in June, 2012. Also, focus group discussion and key informant survey were carried out. The final analysis was done by using computer software Microsoft Excel and STATA 12.

\subsection{Techniques of Data Analysis}

After the collection of necessary information it was coded and entered to computer for analysis. Descriptive statistics using percentage and frequency tables were used in the analysis for the socio-economic characteristics of the sampled farmers.

\subsubsection{Gross Margin and Benefit Cost Analysis}

Important variable cost items were taken under study and to make comparisons more scientific prevailing market price was used for each input used and also for price of output.

$$
\begin{aligned}
& \text { Cost of cauliflower production }=\mathrm{C}_{\text {labor }}+\mathrm{C}_{\text {seed }}+ \\
& \qquad \mathrm{C}_{\text {fert }}+\mathrm{C}_{\text {pesticide }}+\mathrm{C}_{\text {manure }}
\end{aligned}
$$

Where,

$\mathrm{C}_{\text {labor }}=$ Cost of labor used

$\mathrm{C}_{\text {seed }}=$ Expenditure on seed

$\mathrm{C}_{\text {fert }}=$ Expenditure on chemical fertilizer

$\mathrm{C}_{\text {pesticide }}=$ Expenditure on chemical pesticides

$\mathrm{C}_{\text {manure }}=$ Cost of organic manure

Gross margin analysis was done as given by Olukosi et al., (2006) by using formula;

Gross Margin (NRs.) = Gross farm income (NRs.) - Total variable cost (NRs.)

Where, Gross income (NRs.) = Price of cauliflower $(\mathrm{NRs}$.$) \times total quantity sold (\mathrm{Kg}$.)

Total variable cost $(\mathrm{NRs})=$. Summation of cost on all variable inputs.

Benefit cost ratio is the quick and easiest method to determine the economic performance of farm business. Similarly, benefit cost analysis was done using the total variable cost and gross return from the cauliflower. Cost of production was calculated by summing all the variable cost items in the production process. For calculating gross return, income from the sale was accounted. Thus, the benefit cost analysis was carried out by using formula;

$$
B / C \text { ratio }=\frac{\text { Gross return }(N R s .)}{\text { Total variable cost }(N R s .)}
$$

For comparison, before-after approach was used and paired t-test was applied to test the mean difference of cost and return items in SSM based and conventional system of 
cauliflower production in the study site.

\subsubsection{Production Function and Return to Scale Analysis}

Cobb-Douglas type of production function was used to determine the contribution of different factors on production and to estimate the efficiency of the variable factors of producing cauliflower before and after the adoption of SSM practices.

$$
\mathrm{Y}=\mathrm{aX}_{1}{ }^{\mathrm{b} 1} \mathrm{X}_{2}{ }^{\mathrm{b} 2} \mathrm{X}_{3}^{\mathrm{b} 3} \mathrm{X}_{4}{ }^{\mathrm{b} 4} \mathrm{e}^{\mathrm{u}}
$$

Where,

$\mathrm{Y}=$ Total cauliflower production (Kg.)

$\mathrm{X}_{1}=$ Labor (Man-days)

$\mathrm{X}_{2}=$ Expenditure on seed (NRs.)

$\mathrm{X}_{3}=$ Expenditure on Chemical inputs (NRs.)

$\mathrm{X}_{4}=$ Organic manure $($ Doko $)$

$\mathrm{u}=$ Random disturbance term and $\mathrm{b}_{1}, \mathrm{~b}_{2}, \ldots . . \mathrm{b}_{4}$ are the coefficient to be estimated.

The Cobb-Douglas production function in the form expressed above was linearised in to a logarithmic function with a view of getting a form amenable to practical purposes as expresses below;

$$
\ln \mathrm{Y}=\ln \mathrm{a}+\mathrm{b}_{1} \ln \mathrm{X}_{1}+\mathrm{b}_{2} \ln \mathrm{X}_{2}+\mathrm{b}_{3} \ln \mathrm{X}_{3}+\mathrm{b}_{4} \ln \mathrm{X}_{4}+\mathrm{u}
$$

Where,

$\ln =$ Natural logarithm, $a=$ constant and $\mathrm{u}=$ Error term

For the calculation of return to scale from sustainable soil management based cauliflower production and before project, Cobb-Douglas production function was used and calculated using formula;

Return to scale $(\mathrm{RTS})=\sum \mathrm{b}_{\mathrm{i}}$

Where, $b_{i}=$ Coefficient of $i^{\text {th }}$ variables.

\subsubsection{Resource Use Efficiency}

The efficiency of a resource used was determined by the ratio of MVP of inputs (based on the estimated regression coefficients) and the MFC. Following Goni et al. (2007) the efficiency of resource was calculated as;

$$
\mathrm{r}=\mathrm{MVP} / \mathrm{MFC}
$$

Where,

$\mathrm{r}=$ Efficiency ratio

$\mathrm{MVP}=$ Marginal value product of a variable input.

$\mathrm{MFC}=$ Marginal factor cost (Price per unit input)

The value of MVP was estimated using the regression coefficient of each input and the price of the output.

$$
\text { MVP= MPPxi } \times \text { Py (Unit price of output) }
$$

But, MPPxi $=\mathrm{dy} / \mathrm{dxi}=\mathrm{bi \overline {y }} / \mathrm{Xi}$

Where; bi= Estimated regression coefficient of input $\mathrm{Xi}$ $\bar{y}=$ Arithmetic mean value of output.

$\overrightarrow{\mathrm{X} 1}=$ Arithmetic mean value of input being considered.

The prevailing market price of input was used as the Marginal Factor Cost (MFC).
$\mathrm{MFC}=\mathrm{Pxi}$ Where, Pxi= Unit price of input $\mathrm{xi}$.

The decision rule for the efficiency analysis was as;

$\mathrm{r}=1$; Efficient use of a resource

$\mathrm{r}>1$; Underutilization of a resource

$\mathrm{r}<1$; Overutilization of a resource

Again, the relative percentage change in MVP of each resource required so as to obtain optimal resource allocation i.e $\mathrm{r}=1$ or $\mathrm{MVP}=\mathrm{MFC}$ was estimated using the following equation below;

$$
\mathrm{D}=(1-\mathrm{MFC} / \mathrm{MVP}) \times 100
$$

Or, $\mathrm{D}=(1-1 / \mathrm{r}) \times 100$

Where, $\mathrm{D}=$ absolute value of percentage change in MVP of each resource and $\mathrm{r}=$ efficiency ratio.

\section{Results and Discussion}

\subsection{Socio-Demographic Characteristics of Respondent}

Total sampled population in the study area was 357 of which male population was 53.22 percent. Average family size was 5.95 and was higher than the national average 4.5 (CBS, 2011). About 50 percent of the study population was economically active as classified by the Government of Nepal. About 83 percent of household were male headed and 72 percent of the household were found with nuclear family. About 62 percent were found literate and higher illiteracy rate may be due to poor economic status and geographical situation of the study area. Total area owned in an average was 11.90 ropani of which 10.43 ropani was cultivated and only 3.40 ropani was under irrigation. Farmers in the study area perceived irrigation as the major problem hindering the vegetable production. Among the total respondents about 67 percent had received trainings related to sustainable soil management based vegetable farming in the study area.

\subsection{Benefit-Cost and Gross Margin Analysis}

Table 1 depicted that the area of cauliflower under cultivation was significantly increased by 0.52 ropani after adopting SSM practices. Cost of labor and organic manure was significantly increased by NRs. 386.03 and NRs. 651.52 per ropani compared to before. Per ropani cost on chemical fertilizers and pesticides was significantly decreased by NRs.735.31 and NRs. 728.89 respectively. Although, total cost of cultivation and average cost were insignificant and were lower by NRs. 423.72 and NRS 0.46 respectively. The result exactly agree with the findings of Satpute et al. (2009) who studied on costs, returns and resource use efficiency in organic and inorganic cotton farming in Parbhani district, India. Finding of Kawasaki and Fujimoto (2009) also support this result which concluded lower total cost of production of organic Yard long bean compared to conventional system. 
Table 1. Comparative cost of cauliflower cultivation before and after SSM practices in the study area

\begin{tabular}{llllll}
\hline Particulars & SSM based & Before SSMP & Mean Difference & t-value & Level of Significance \\
\hline Area (Ropani) & 2.15 & 1.63 & $0.52^{* * *}$ & 4.025 & 0.0001 \\
Labor Cost(NRs./Ropani) & 1812.92 & 1426.88 & $386.03^{* * *}$ & 3.289 & 0.0008 \\
Cost of Seed(NRs./Ropani) & 331.5 & 320.05 & 11.44 & 0.573 & 0.2841 \\
Total Manure Cost(NRs./Ropani) & 2092.75 & 1441.22 & $651.52^{* * *}$ & 7.253 & 0.0000 \\
Cost of Chemical Fertilizer(NRs./Ropani) & 471.15 & 1206.47 & $-735.31^{* * *}$ & -9.710 & 0.0000 \\
Cost of Pesticides(NRs./Ropani) & 110.21 & 839.11 & $-728.89^{* * *}$ & -10.603 & 0.0000 \\
Total cost of cultivation(NRs./Ropani) & 5605.606 & 6029.33 & -423.72 & -1.357 & 0.0900 \\
Average cost (NRs./Kg) & 8.76 & 9.22 & -0.46 & -0.763 & 0.2243 \\
\hline
\end{tabular}

*** Significant at 1\% level Source: Field survey, 2012

** Significant at 5\% level

$\mathrm{SSMP}=$ Sustainable soil management program

Buying rate of 1 US $\$=95.91$. NRs. (Nepalese Rupees) as of July 29, 2014.

19.66 Ropani $=1$ Hectare

Similarly, table 2 revealed that gross income, gross margin and benefit cost ratio were significant different before and after adopting SSM Practices. Result showed that the productivity of cauliflower decreased by 0.31 quintal on SSM-based production system. This finding is in line with the finding of Kshirsagar (2006) who reported that the organic farmers realized 7.17 percent lower yield than inorganic farmers in India. Gross income and gross margin were increased by NRs. 1749.58 and 2173.36 respectively whereas benefit cost ratio was higher by 0.41 compared to before SSM practice and were significant at 5 percent level (Table 4). Result is in line with Adhikari (2009) who reported higher cost and higher revenue in inorganic production system but higher benefit cost ratio in organic production system of carrot in Nepal. Also the findings are in conformity with the study conducted by Bharadwaj et al. (2000) and Patil (2008).

Table 2. Comparative return from Cauliflower cultivation before and after SSM practices in the study area

\begin{tabular}{llllll}
\hline Particulars & SSM based & Before SSMP & Mean Difference & t-value & Level of Significance \\
\hline Productivity(qt1/Ropani) & 7.00 & 7.31 & -0.31 & -1.181 & 0.1211 \\
Gross Income(NRs./Ropani) & 22565.56 & 20815.97 & $1749.58^{* *}$ & 1.934 & 0.0289 \\
Gross margin (NRs./Ropani) & 16959.95 & 14786.64 & $2173.36^{* * *}$ & 2.668 & 0.0049 \\
B:C Ratio & 4.26 & 3.85 & $0.41 * *$ & 2.311 & 0.0121 \\
\hline
\end{tabular}

*** Significant at 1\% level Source: Field survey, 2012

** Significant at $5 \%$ level

\subsection{Production Function Analysis}

Result of production function analysis revealed that the values of coefficient of multiple determinations were 0.60 and 0.56 indicating that $60 \%$ and $56 \%$ of the variations in production of cauliflower was explained by the explanatory variables included in the model for SSM-based and before SSMP respectively. The f-values were 21.23 and 18.03 for after and before SSMP respectively which were highly significant at $1 \%$ confidence level implying that the variation of yield mainly depends on the explanatory variables included in the model. The estimated value of coefficients and related statistics of Cobb-Douglas production function were presented in table 3 .

Model resulted that the coefficient of hired human labor for both before and SSM-based production were 0.027 and 0.029 respectively, and were positive and significant at $5 \%$ level of confidence indicating that 1 percent increase in the use of hired human labor, keeping other factors constant would increase the yield of cauliflower by 0.027 and 0.029 percent. Result is similar with that of Chithra et al. (2008) and Bakhsh et al. (2007).

The coefficients of expenditure on seed were positive and significant for both before and for SSM-based production. Keeping all other factor constant, 1\% increase in expenditure on seed would increase the yield of cauliflower by 0.376 and 0.362 percent respectively (Table $3)$. Result agrees to that of Hassan et al. (2005).

Coefficient of expenditure on chemical inputs was significant for SSM-based production system and $1 \%$ increase in expenditure on chemical inputs, keeping all other factors constant there would be increase in production by 0.177 percent. But for before SSMP the value of coefficient was 0.196 and was negative indicating that yield would decrease by 0.196 if further increased in chemical inputs (Table 3).

The regression coefficient of organic manure was positive and significant at $1 \%$ level of confidence for before SSM practices. It indicates that keeping all other factors constant, a unit increase in organic manure would increase yield of cauliflower by 0.390 percent. Whereas, in case of SSM based cauliflower production use of organic manure was positive and insignificant (Table 3). Similar to this, Akter et al., (2011) using revenue type of CobbDouglas production function resulted manure cost as significant factor in tomato production. 
Table 3. Estimated coefficients and their related statistics of production function for cauliflower in the study area

\begin{tabular}{llll}
\hline \multirow{2}{*}{ Explanatory variables } & SSM based & & Before SSMP \\
\cline { 2 - 4 } & Coefficient & t-value & Coefficient \\
\hline Constant & $2.716(0.680)$ & 3.99 & $4.953(1.181)$ \\
Human labor $\left(\mathrm{X}_{1}\right)$ & $0.027(0.012)^{* *}$ & 2.18 & $0.029(0.014)^{* *}$ \\
Expenditure on seed $\left(\mathrm{X}_{2}\right)$ & $0.362(0.135)^{* *}$ & 2.68 & $0.376(0.134)^{* * *}$ \\
Chemical inputs $\left(\mathrm{X}_{3}\right)$ & $0.177(0.089)^{* *}$ & 1.98 & $-0.196(0.135)$ \\
Organic manure $\left(\mathrm{X}_{4}\right)$ & $0.236(0.155)$ & 1.52 & $0.390(0.145)^{* *}$ \\
$\mathrm{R}^{2}$ & 0.60 & & 0.56 \\
F-value & 21.23 & & -1.45 \\
Return to Scale $\left(\sum\right.$ bi & 0.802 & & 2.80 \\
\hline
\end{tabular}

Figure in parentheses indicate standard error. Source: Field survey, 2012 $\mathrm{SSMP}=$ Sustainable soil management program

*** Significant at $1 \%$ level

** Significant at 5\% level

\subsection{Return to Scale Analysis}

Regression coefficients of the estimated production function of cauliflower for SSM-based and before SSM practices were 0.802 and 0.599 respectively (Table 3 ). This result implies that the production function exhibits decreasing return to scale. In this case, if all the variables specified in the production function were increased by one percent, production of cauliflower would increase by 0.802 percent and 0.599 percent for SSM-based and before SSM practices respectively. Similar to this Wosor and Nimoh, (2012) reported decreasing return to scale in chilli pepper production with value 0.304. Also, Akter et al., (2011) reported decreasing return to scale in tomato production with value 0.571 .

\subsection{Analysis of Resource Use Efficiency}

The value of $r$ was greater than unity for all the variable inputs used in cauliflower production except in expenditure on human labor as presented in table 4. This implies that expenditure on human labor in SSM based cauliflower production was over utilized whereas, expenditure on chemical inputs, expenditure on seed and organic manure were underutilized in SSM-based production system. Study result showed that all the inputs were not utilized to optimum economic advantage. Result agrees with the findings of Goni et al. (2013).

Result revealed that chemical inputs, seed and organic manure were underutilized whereas human labor was over utilized by the producers. To ensure optimum use of resources in SSM-based cauliflower production, expenditure on chemical inputs, seed and organic manure is required to increase by 87.5 percent, 96.1 percent and 72.0 percent respectively whereas, expenditure on human labor is required to decrease by 116.0 percent (Table 4). Producers can decrease the cost of production by reducing human labor and can increase the production by increasing the use of other inputs. Result is similar with the findings of Kehinde et al., (2012). Similarly, Chapke et al., (2011) also reported that for optimum allocation of resources more than 88 percent increase in fertilizer, 76 percent in labor and 30 percent in agrochemicals was needed whereas, 127 percent and 114 percent reduction was required for seed and irrigation for sorghum production in India.

Table 4. Estimated resource use efficiency and required adjustment in Marginal Value Product (MVP) in percentage for SSM based cauliflower production in the study area

\begin{tabular}{|c|c|c|c|c|c|}
\hline Variable inputs & Coefficient value & MVP & MFC & $\mathbf{r}$ & D \\
\hline Human labor (Man-days) & 0.027 & 128.04 & 276.6 & 0.46 & 116.0 \\
\hline Expenditure on seed (NRs.) & 0.362 & 25.85 & 1 & 25.85 & 96.1 \\
\hline Expenditure on chemical inputs (NRs.) & 0.177 & 8.02 & 1 & 8.02 & 87.5 \\
\hline Organic Manure (Doko) & 0.236 & 164.58 & 46 & 3.58 & 72.0 \\
\hline
\end{tabular}

MVP= Marginal Value Product

$\mathrm{MFC}=$ Marginal Factor Cost

$\mathrm{r}=$ Efficiency ratio (MVP/MFC)

$\mathrm{D}=$ Absolute value of percentage change in MVP of each resource

\section{Conclusion and Recommendations}

The study has concluded that sustainable soil management based cauliflower production is a highly profitable enterprise in the study area as it showed decreased cost of production, higher benefit cost ratio and higher return to scale compared with before. Human labor, expenditure on seed, expenditure on chemical inputs and organic manure were the most determining factors in cauliflower production. Findings of this study revealed that 
SSM based cauliflower producers in the study area were technically inefficient in the use of farm resources. Most of the inputs in SSM based cauliflower production were underutilized and it shows great opportunity of increasing productivity and income. On the basis of the findings, the study recommends that the farmers should reduce the level of those inputs that are being over used. Thus, to obtain economic advantage, farmers are recommended to reduce labor force and increase expenditure in seed and organic manure. Although chemical inputs are also underutilized, judicious use of such inputs should be done to ensure sustainability of soil and cauliflower production. Since, Nepal is facing the problem of scarcity, inaccessibility, toxicity and timely unavailability of chemical fertilizers these practices will be a best alternatives. Based on the discoveries of this study, it is recommended that, Government of Nepal should implement the intensive program related to sustainable soil management for producing diverse crops in different districts of the country. Provision of providing subsidized inputs, trainings and other demonstration program from Government level may also help farmer for better adoption of SSM practices and on the other hand also decreases the pressure on demand for chemical inputs.

\section{Acknowledgements}

We are thankful to IAAS (Institute of Agriculture and Animal Science), Department of Agricultural Economics, (IAAS) and Directorate of Research, (IAAS) Rampur, Chitwan, Nepal. We are cordially indebted to the financial support by Sustainable Soil Management Program (SSMP)HELVETAS, Nepal for this study. We would also like to express our deepest gratitude to our colleagues for their direct and indirect help for the completion of research and heartwarming appreciation goes to respondents of the study site for their cooperation, time and valuable information.

\section{References}

[1] Adhikari R.K. (2009). Economics of organic vs inorganic carrot production in Nepal Journal of Agriculture and Environment.10:23-28.

[2] Akter S., M.S. Islam and M.S. Rahman. (2011). An economic analysis of winter vegetable production in some selected areas of Narsingdi district. Journal of Bangladesh Agriculture University. 9(2): 241-246.

[3] Awasthi B.D. (2003). Vegetable production and marketing in Kathmandu valley. Community Rural Development Society, Devinagar, Kathmandu, Nepal.

[4] Bakhsh K, B. Ahmad, S. Hassan and Z.A. Gill. (2007). An analysis of technical efficiency of growing bitter gourd in Pakistani Punjab. Pakistan Journal of Agriculture Science. 44(2):350-355.

[5] Bhardwaj M.L, R. Harender and B.L. Koul. (2000). Yield response and economics of organic sources of nutrients as substitute to inorganic sources in tomato, okra, cabbage and cauliflower. Journal of Agriculture Science. 70(10):653-656.

[6] CBS. (2011). Population census report. Central Bureau of Statistics, Singha Durbar, Kathmandu Nepal. pp. 120-268.

[7] Chapke R.R., B. Mondal and J.S. Mishra. (2011). Resource use efficiency of sorghum production in Rice- fallows in Andhra Pradesh. Indian Journal of Human Ecology. 34(2): 87-90.

[8] Chithra M.S., K.J. Thomas, J.C. Laly and E.K. Thomas. (2008). Technical efficiency in bitter gourd production. The ICFAI Journal of Agriculture Economics. 5(2):41-47.

[9] FORWARD. (2006). Annual Progress Report on "Promotion of integrated plant nutrition system (IPNS) in Maize-based Systems in the Hilly Areas of Makawanpur District". Bharatpur: FORWARD, Nepal. 17p.

[10] Goni M., M. Mohammed, B.A. Sandbaba. (2007). Analysis of resource use efficiency in rice production in the Lake Chad Area of Bomo State, Nigeria. Journal of Sustainable Development and Agriculture Environment. 3: 31-37.

[11] Goni M., M. Umar, A.S. S and U. Sman. (2013). Analysis of resource-use efficiency in dry season vegetable production in Jere Borno State, Nigeria. Journal of Biology and Agriculture Health. 3(19): 18-23.

[12] Hassan I., K. Bakhsh, M.H. Salik, M. Khalil and N. Ahmad. (2005). Profitability of winter vegetables in Faisalabad (Pakistan). International Journal of Agriculture Biology. 2:321-322.

[13] Kawasaki J. and F. Akimi. (2009). Economic and technical assessment of organic vegetable farming in comparison with other production systems in Chiang Mai, Thiland. Journal of ISSAAS 15(1):144-169.

[14] Kehinde F.T., J.O. Olukosi, A..L Ala, M.A. Maikasuwa and A.A. Odunsi. (2012). Determinants of the level of resource use efficiency in quality protein maize production in Kaduna State, Nigeria. International Journal of Applied Agriculture and Apiculture Research. 8(2): 24-30.

[15] KFVMDB. (2012). Annual report. Kalimati Fruit and Vegetable Market Development Board. Ministry of Agricultural Development, Kathmandu, Nepal.

[16] Kshirsagar K.G. (2006). Organic sugarcane farming for development of sustainable agriculture in Maharastra. Journal of Agriculture Ecology. 19: 145-153.

[17] MoAD. (2012). Statistical information on Nepalese agriculture. Ministry of Agriculture and Development. AgriBusiness Promotion and Statistics Division (ABPSD), Kathmandu, Nepal.

[18] NARC. (2006). A Quarterly Newsletter. Nepal Agricultural Research Council. April-June 2006. 13(2).

[19] Noorivandi A.N., A. Ajili, M. Chizari and M. Bijani. (2009). The socio-economic characteristics of wheat farmers regarding adoption of sustainable soil management. Journal of Human Ecology. 27(3): 201-205.

[20] Olukosi J.O., S.U. Isitor and M.O. Ode. (2006). Introduction to agricultural marketing and prices: principle and application. 115 p. Living Book Series, GU publications Abuja. 
[21] Patil M. (2008). A study on production and marketing management behavior of organic vegetable growers in Belgaum district. Master Thesis. University of Agricultural Science, Dharwad (India).

[22] Poate, C.D. and P.F. Daplyn. (1993). Data for Agrarian Development. Cambridge University Press.
[23] Satpute T.G., S.S. More and D.J. Sanap. (2009). Costs, returns and resource use efficiency in organic and inorganic cotton farming in Parbhani district. Journal Agriculture Update. 4(1):138-142.

[24] SSMP. (2009). Farmer Profiles from the Mid-hills of Nepal. Sustainable Soil Management Program, Kathmandu, Nepal. $112 \mathrm{p}$. 